\title{
СТРУКТУРА УПРАВЛІНСЬКОЇ КОМПЕТЕНТНОСТІ ДИРЕКТОРА ШКОЛИ МИСТЕЦТВ У КОНТЕКСТІ РЕФОРМИ МИСТЕЦЬКОЇ ОСВІТИ
}

\author{
Свгенія Гринь \\ директор школи мистецтв м. Бахмут, \\ викладач вищої категорії, методист \\ м. Бахмут, Донецька обл., Україна \\ https://orcid.org/0000-0001-6282-0387 \\ genyakibkalo@gmail.com
}

Анотація. У статті розглядається питання глобальних змін, котрі відбуваються в системі мистецької освіти та висувають нові вимоги до управління мистецькою школою, що так само спричиняє потребу у формуванні нового рівня управлінської компетентності іiі директора. Подано аналіз наукових підходів до визначення сутності та структури управлінської компетентності директора мистецької школи, спираючись на який, авторка пропонує власне тлумачення цього поняття і розкриває структуру та характеризує основні компоненти управлінської компетентності з урахуванням сучасних суспільних й освітніх інноваційних процесів. Схарактеризовано критерії та рівні сформованості управлінської компетентності директора мистецької школи. Визначено характерологічні риси інноваційної особистості директора мистецької школи в контексті реформування освіти.

Ключові слова: мистецька освіта; управлінська компетентність; мистецька школа; директор; компоненти; критерії.

Постановка проблеми в загальному вигляді. У сучасних умовах реалізації Закону України «Про освіту», Концепції сучасної мистецької школи, формування національної соціально орієнтованої інноваційної системи, що забезпечує побудову економіки, заснованої на знаннях і розвитку людського капіталу; основою динамічного економічного зростання і соціального розвитку українського суспільства визначено модернізацію системи освіти, яка $\epsilon$ фактором благополуччя громадян і безпеки країни [1]. Основними тенденціями розвитку мистецької освіти на сучасному етапі А. Козир визначає гуманізацію, гуманітаризацію, національну спрямованість, соціокультурну відповідність, відкритість; перенесення акценту 3 навчальної діяльності на навчальнопізнавальну, художню; перехід від репродукування до розуміння, осмислення; створення умов для самореалізації; педагогічна взаємодія, співробітництво; спрямованість освітнього процесу на виявлення творчих можливостей; акмеологічне спрямування розвитку особистості [5].

У період докорінної модернізації системи освіти проблема розвитку управлінський компетентності керівників закладів середньої освіти і мистецьких шкіл, а також формування корпусу керівників нового, креативного, інноваційного типу, готового i здатного до ініціативи i нестандартних управлінських рішень, стає особливо актуальною. 
Відсутність у більшості керівників закладів середньої освіти, а також мистецьких шкіл необхідного рівня управлінської компетентності серйозно ускладнює їх адаптацію до нових умов діяльності, здійснення модернізації освіти і успішне перетворення, очолюваних ними установ в новому статусі згідно 3 Концепцією сучасної мистецької школи [2]. Новій школі потрібен керівник нового типу, який володіє високим рівнем розвитку управлінської компетентності, що забезпечує виконання поряд із традиційними функціями ряду нових функцій, серед яких: прогнозування розвитку, управління якістю і змінами, виявлення і підтримка інновацій, управління своїм часом і часом підлеглих, фандрейзинг та маркетинг, бренд-менеджмент тощо.

Керівник нового типу повинен бути не тільки харизматичним лідером, професіоналом із педагогічною освітою, а й володіти кваліфікацією «менеджера освіти», володіти навичками стратегічного проектування, моніторингу та системного моделювання процесів, що протікають в установі, організації ефективних міжособистісних і професійних комунікацій в колективі, отримання та ефективного застосування інформації, знань тощо.

Особливу значущість для ефективного управління сучасним освітнім закладом набувають особистість керівника, його досвід, ділові та характерологічні особливості. Професія керівника сучасного навчального закладу характеризується високим ступенем витрачання фізичних і духовних сил, вимагає сильного енергетичного потенціалу, доброго здоров'я і вміння підтримувати його в порядку, великого емоційного напруження, розумових i фізичних витрат.

Професія керівника вимагає не тільки нормативно регламентованих, а й творчих, нестандартних, організаційних дій, що сприяють розвитку особистості самого керівника, які формують його мотиваційну сферу, змінюють ціннісні орієнтації Керівник школи нового типу повинен володіти цілісним образним мисленням, розуміти сенс людського існування не 3 точки зору утилітарної, сьогочасної особистої вигоди, а 3 точки зору духовного ноосферного обгрунтування, заснованого на принципах екологічності та синергії - охорони i підтримки життя на Землі всього соціуму і кожної особистості окремо. У процесі здійснення будь-якої управлінської діяльності періодично виникають ті чи інші проблеми.

Аналіз останніх досліджень і публікацій. У дослідженнях Л. Даниленко та Л. Карамушки компетентність керівника загальноосвітнього навчального закладу становить сукупність необхідних для ефективної професійної діяльності систематичних науково-філософських, суспільно-політичних, психологопедагогічних, предметних та соціально-функціональних знань i вмінь, відповідних особистісних якостей [3].

В. Маслов під компетентністю керівника розуміє систему теоретикометодологічних, нормативних положень, наукових знань, організаційнометодичні й технологічні вміння, які необхідні особистості для виконання 
посадово-функціональних обов'язків [7]. Як стверджує Л. Васильченко, компетентність - особливий тип організації знань, що забезпечує можливість прийняття ефективних рішень [5]. Т. Сорочан розглядає поняття «компетентність керівника ЗНЗ» як єдність психологічної, теоретичної i практичної готовності до управлінської діяльності відповідно до конкретних вимог і завдань [9]

Аналіз різних підходів до визначення проблеми компетентності в цілому свідчить, що більшість дослідників пов'язують ії це поняття з певною галуззю діяльності, 3 конкретною професією в матеріальні та духовних сферах. Компетентність - це здатність до актуального виконання діяльності [8]. У зв'язку 3 цим актуальним виявляється аналіз проблеми розвитку рівня управлінської професійної компетентності - управлінської кваліфікації керівника ЗНЗ як складової його управлінської культури. Питанням компетентності в управлінський діяльності керівника пов'язується із професіоналізмом, і тому категорія «професійна компетентність» визначатиметься рівнем професійної освіти i досвідом. Індивідуальними здібностями i якостями керівника, мотивованим прагненням до неперервної самоосвіти і самовдосконалення, творчим і відповідальним ставленням до справи [6].

На думку авторів Л. Даниленко та Л. Карамушки професійна компетентність керівника навчального закладу визначається сукупністю таких компонентів:

- знання, необхідні знання для педагогічної спеціальності або посади;

- уміння і навички, які потрібні для успішного виконання функціональнопосадових обов'язків;

- професійні, ділові та особистісно значущі якості, що сприяють якнайповнішій реалізації власних сил, здібностей і можливостей у процесі виконання функціонально-посадових обов'язків;

- загальна культура, необхідна для формування гуманістичного світогляду, визнання духовно-ціннісних орієнтирів, моральних i етичних принципів особистості;

- мотивація професійної діяльності [4].

Рівень управлінської компетентності визначається тим, як керівник сучасної школи вирішує проблеми, які з'являються.

Формулювання цілей статті (постановка завдання). Для розгляду пропонованих нами шляхів розвитку управлінської компетентності керівників нового типу для мистецької школи необхідно виявити основні вимоги до цих керівників і визначити зміст управлінської компетентності керівників нового типу, що й становить мету статті.

Результати дослідження. Погоджуючись із В. Локшиним і Т. Сорочан [6; 9], під управлінської компетентністю керівника школи мистецтв розуміємо його здатність і готовність цілісно і глибоко аналізувати, виявляти, точно формулювати проблеми освітнього закладу і знаходити 3 більшого числа 
альтернативних підходів до їх вирішення найбільш доцільний і ефективний щодо конкретної ситуації цієї установи.

На основі аналізу результатів дослідження і управлінської, педагогічної практики можемо висновувати, що $\epsilon$ чотири основних функціональних компоненти управлінської компетентності директора мистецької школи: когнітивний, організаційний, комунікативний, рефлексивний. Для кожного 3 чотирьох компонентів визначено склад функцій, освоєння способів виконання яких дозволить сформувати операційний комплекс педагогічної та управлінської діяльності директора мистецької школи, тобто відповідні вміння, способи дій керівника освітнього закладу, які при певному досвіді роботи повинні перейти в навички, а також не менш важливу складову управлінської компетентності професійно значущі якості особистості, що сприяють ефективному вирішенню управлінських проблем.

Запропонована структура управлінської компетентності директора мистецької школи в єдності і взаємозв'язку іiі компонентів представлена за наступними критеріями:

- управлінське та педагогічне мислення; повнота, глибина, системність управлінських, педагогічних, правових, економічних і спеціальних знань в сфері освіти і застосування їх у вирішенні професійно-педагогічних і управлінських ситуацій; усвідомлення управлінських і педагогічних цінностей; аргументоване висування нестандартних рішень i алгоритмів управлінської, педагогічної, предметно-практичної діяльності (когнітивний компонент);

- здійснення комплексу організаційних заходів, спрямованих на виконання мети i завдань установи; мобілізація колективу на оптимально ефективні професійні дії по реалізації місії; забезпечення сприятливих умов для розвитку підлеглих і установи; вміння управляти своїм часом і часом підлеглих, володіння навичками само-менеджменту (організаційний компонент);

- висока здатність впливати на думку оточуючих; продуктивну взаємодію в управлінській діяльності, толерантне сприйняття партнерів на основі емпатійних установок; професійно-групова причетність, уміння сформувати команду однодумців (комунікативний компонент);

- професійна саморегуляція, вміння володіти проявом своїх почуттів; корекція власної поведінки і діяльності щодо поставлених цілей, конкретної ситуації і результатів самопізнання власних ділових, особистісних якостей i психофізичних особливостей; асиміляція освітнього середовища, адекватна самооцінка і самоаналіз управлінської діяльності; приборкання несвідомих реакцій організму і психіки з метою запобігання відмов уваги, примх пам'яті, некерованих емоцій (рефлексивний компонент).

Пропонуємо критеріальні характеристики, що відображають чотирирівневий прояв сформованості управлінської компетентності директорів мистецьких шкіл у контексті реформи: низький рівень, що характеризується актуалізацією інтелектуальних стереотипів; середній рівень - актуалізацією 
особистісних стереотипів; достатньому рівню властиво формування особистісних новоутворень; високий рівень характеризується появою особистісних новоутворень.

Критеріальні характеристики визначених рівнів сформованості управлінської компетентності директорів мистецьких шкіл представлені в таблиці.

Таблиия 1.

\section{Критеріальні характеристики рівнів сформованості управлінської компетентності директорів мистецьких шкіл}

\begin{tabular}{|c|c|c|c|c|}
\hline Рівень & $\begin{array}{l}\text { Когнітивний } \\
\text { компонент }\end{array}$ & $\begin{array}{l}\text { Організаційний } \\
\text { компонент }\end{array}$ & $\begin{array}{l}\text { Комунікативний } \\
\text { компонент }\end{array}$ & $\begin{array}{l}\text { Рефлексивний } \\
\text { компонент }\end{array}$ \\
\hline Ий & $\begin{array}{l}\text { Недостатня } \\
\text { сформованість } \\
\text { управлінського і } \\
\text { педагогічного } \\
\text { мислення. } \\
\text { Управлінські і } \\
\text { спеціальні знання, } \\
\text { уміння та навички } \\
\text { мають } \\
\text { ситуативний, } \\
\text { поверхневий } \\
\text { характер. }\end{array}$ & $\begin{array}{l}\text { Iніціація } \\
\text { організаційної } \\
\text { діяльності, проте } \\
\text { здатність до іï } \\
\text { підтримки } \\
\text { розвинена } \\
\text { недостатньо. } \\
\text { Вибіркове } \\
\text { включення } \\
\text { управлінську } \\
\text { діяльність } \\
\text { дозволяє } \\
\text { проектувати } \\
\text { організаційну } \\
\text { структуру } \\
\text { управління } \\
\text { установою. } \\
\text { Відсутність } \\
\text { навичок } \\
\text { самоменеджменту. }\end{array}$ & $\begin{array}{l}\text { Нездатність до } \\
\text { професійних } \\
\text { контактів. Участь } \\
\text { у професійній } \\
\text { діяльності і } \\
\text { управлінському } \\
\text { спілкуванні } \\
\text { завдяки } \\
\text { вимушеній } \\
\text { мотивації. } \\
\text { Уникання } \\
\text { виступів перед } \\
\text { аудиторією. }\end{array}$ & $\begin{array}{l}\text { Нерозвиненість } \\
\text { рефлексивних } \\
\text { здібностей. } \\
\text { Заниженість } \\
\text { власної } \\
\text { самооцінки, } \\
\text { незнання } \\
\text { неволодіння } \\
\text { основними } \\
\text { прийомами } \\
\text { самоаналізу та } \\
\text { саморегуляції. } \\
\text { Нездатність } \\
\text { вплинути } \\
\text { думку партнера } \\
\text { по спільній } \\
\text { діяльності } \\
\text { думку підлеглих. }\end{array}$ \\
\hline & $\begin{array}{l}\text { Орієнтованість на } \\
\text { застосування } \\
\text { управлінських і } \\
\text { спеціальних знань } \\
\text { у вирішенні } \\
\text { управлінських } \\
\text { ситуацій, } \\
\text { недостатня } \\
\text { аргументованість } \\
\text { своїх поглядів у } \\
\text { вирішенні } \\
\text { управлінських і } \\
\text { виробничих } \\
\text { завдань. Здатність } \\
\text { до репродуктивної }\end{array}$ & $\begin{array}{l}\text { Здійснення } \\
\text { комплексу } \\
\text { організаційних } \\
\text { заходів на } \\
\text { низькому } \\
\text { професійному } \\
\text { рівні. Нестійкість } \\
\text { стилю управління, } \\
\text { який часом не } \\
\text { відповідає цілям і } \\
\text { завданням } \\
\text { установи. } \\
\text { Організованість } \\
\text { умов для розвитку } \\
\text { підлеглих }\end{array}$ & 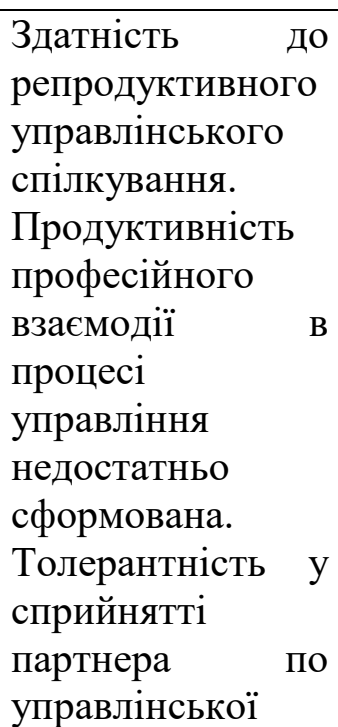 & $\begin{array}{l}\text { Неадекватність } \\
\text { самооцінки, } \\
\text { значущості } \\
\text { власної участі в } \\
\text { спільній } \\
\text { педагогічній } \\
\text { управлінській } \\
\text { діяльності. } \\
\text { Здатність } \\
\text { впливати } \\
\text { результати } \\
\text { управлінської, } \\
\text { професійної } \\
\text { діяльності носить }\end{array}$ \\
\hline
\end{tabular}


ЄВГЕНІЯ ГРИНЬ

Структура управлінської компетентності директора школи мистецтв у контексті реформи мистецької освіти

\begin{tabular}{|c|c|c|c|c|}
\hline & $\begin{array}{l}\text { управлінської } \\
\text { діяльності. }\end{array}$ & $\begin{array}{l}\text { установи слабо } \\
\text { виражена. } \\
\text { Володіння } \\
\text { навичками } \\
\text { самоменеджменту } \\
\text { на низькому рівні. }\end{array}$ & $\begin{array}{l}\text { діяльності слабо } \\
\text { виражена або не } \\
\text { розвинена. }\end{array}$ & $\begin{array}{l}\text { ситуативний } \\
\text { характер. }\end{array}$ \\
\hline Дос & $\begin{array}{l}\text { Активність } \\
\text { використання } \\
\text { управлінських і } \\
\text { спеціальних знань } \\
\text { при вирішенні } \\
\text { виробничих і } \\
\text { управлінських } \\
\text { завдань, } \\
\text { аргументованість } \\
\text { відстоювання } \\
\text { своїх професійних } \\
\text { поглядів. } \\
\text { Продуктивність } \\
\text { оперування } \\
\text { управлінськими, } \\
\text { спеціальними } \\
\text { знаннями, } \\
\text { уміннями, } \\
\text { навичками }\end{array}$ & $\begin{array}{l}\text { Продуктивність } \\
\text { організаційних } \\
\text { заходів, здатність } \\
\text { до вибору } \\
\text { оптимального } \\
\text { стилю управління і } \\
\text { проектування } \\
\text { ефективної } \\
\text { організаційної } \\
\text { структури } \\
\text { управління } \\
\text { установою. } \\
\text { Володіння } \\
\text { навичками } \\
\text { самоменеджменту } \\
\text { на продуктивному } \\
\text { рівні. здатність } \\
\text { створення умов } \\
\text { для розвитку } \\
\text { підлеглих } \\
\text { установи i }\end{array}$ & $\begin{array}{l}\text { Толерантність у } \\
\text { сприйнятті } \\
\text { партнера } \\
\text { управлінської по } \\
\text { діяльності досить } \\
\text { розвинена. } \\
\text { Виражене і стійке } \\
\text { прагнення до } \\
\text { продуктивного } \\
\text { спілкування в } \\
\text { управлінській } \\
\text { діяльності }\end{array}$ & $\begin{array}{l}\text { Адекватність } \\
\text { самооцінки своєї } \\
\text { професійно- } \\
\text { управлінської } \\
\text { ролі у виконанні } \\
\text { спільної } \\
\text { професійної } \\
\text { діяльності. } \\
\text { Здатність до } \\
\text { професійної } \\
\text { взаємодії має } \\
\text { продуктивний } \\
\text { характер. } \\
\text { Організовує } \\
\text { подальші } \\
\text { керуючись дї, } \\
\text { ціннісними } \\
\text { орієнтирами. } \\
\text { Володіє } \\
\text { методикою } \\
\text { самоаналізу } \\
\text { саморегуляції }\end{array}$ \\
\hline & $\begin{array}{l}\text { Творчий підхід до } \\
\text { вибору форм і } \\
\text { методів } \\
\text { управління. } \\
\text { Нестандартність } \\
\text { застосування } \\
\text { управлінських і } \\
\text { спеціальних знань } \\
\text { при рішенні } \\
\text { виробничих і } \\
\text { управлінських } \\
\text { завдань. } \\
\text { Аргументованість } \\
\text { висунення } \\
\text { власного } \\
\text { алгоритму } \\
\text { діяльності та його } \\
\text { відстоювання. } \\
\text { здатність до } \\
\text { інновацій } \\
\text { раціоналізаторства }\end{array}$ & $\begin{array}{l}\text { Творчий підхід до } \\
\text { вибору } \\
\text { організаційної } \\
\text { структури } \\
\text { управління. } \\
\text { Володіння } \\
\text { навичками } \\
\text { самоменеджменту } \\
\text { на творчому рівні. } \\
\text { Здатність до } \\
\text { створення } \\
\text { оптимально } \\
\text { ефективних умов } \\
\text { для розвитку } \\
\text { підлеглих } \\
\text { установи. } \\
\text { Володіння } \\
\text { власним } \\
\text { авторським } \\
\text { стилем } \\
\text { управління. }\end{array}$ & $\begin{array}{l}\text { Толерантність у } \\
\text { сприйнятті } \\
\text { партнера по } \\
\text { управлінської } \\
\text { діяльності добре } \\
\text { розвинена. } \\
\text { Продуктивність } \\
\text { спілкування має } \\
\text { творчий, стійкий } \\
\text { характер. Мета - } \\
\text { розвиток } \\
\text { підлеглих, } \\
\text { враховуючи їхні } \\
\text { вікові, } \\
\text { психофізіологічні } \\
\text { особливості } \\
\text { рівень } \\
\text { професіоналізму. } \\
\text { Висока здатність } \\
\text { впливати } \\
\text { думку на }\end{array}$ & $\begin{array}{l}\text { Професійна } \\
\text { саморегуляція, } \\
\text { інтегральний } \\
\text { локус-контроль. } \\
\text { Адекватність } \\
\text { самооцінки. } \\
\text { Здатність } \\
\text { впливати на } \\
\text { результати } \\
\text { управлінської } \\
\text { діяльності, } \\
\text { корекція власної } \\
\text { поведінки } \\
\text { діяльності щодо } \\
\text { поставлених } \\
\text { цілей, конкретної } \\
\text { ситуації } \\
\text { результатів і } \\
\text { самопізнання } \\
\text { власних ділових і } \\
\text { особистісно- }\end{array}$ \\
\hline
\end{tabular}


ЄВГЕНІЯ ГРИНЬ

Структура управлінської компетентності директора школи мистецтв у контексті реформи мистецької освіти

\begin{tabular}{|l|l|l|l|l|}
\hline & $\begin{array}{l}\text { Уміння ефективно } \\
\text { i творчо управляти } \\
\text { своїм часом i } \\
\text { часом підлеглих }\end{array}$ & $\begin{array}{l}\text { оточуючих, } \\
\text { сміння } \\
\text { сформувати } \\
\text { команду } \\
\text { однодумців }\end{array}$ & осихологічних \\
особливостей \\
\end{tabular}

Керівник школи мистецтв нового типу повинен володіти управлінською компетентністю, що включає як професійні, так і особистісно-соціальні компоненти компетентності на вищому, креативному рівні їі розвитку.

Рішення розглянутої нами проблеми розвитку управлінської компетентності директора мистецької школи у контексті реформування мистецької освіти бачиться декількома шляхами.

Керівників нового типу для нової школи мистецтв можна умовно розділити на дві групи. Перша включає діючих в даний час перспективних директорів мистецьких шкіл та їх заступників, керівників структурних підрозділів, які мають практичний досвід, володіють певним вже сформованим рівнем управлінської компетентності, готових і здатних розвивати свою управлінську компетентність до вищого, креативного рівня. I друга - кадровий резерв керівників нового типу, який необхідно активно формувати.

Очевидно, що серед цих груп керівників нового типу не може бути директорів, які не перспективні, не готові i не здатні розвивати свою управлінську компетентність, а значить - змінюватися і безперервно підвищувати свою кваліфікацію як менеджера освіти. Постійне оновлення діяльності менеджерів освіти передбачає формування у них інноваційного мислення і лідерських якостей, спрямованих на вирішення складних завдань соціально-інноваційного управління освітньою установою, набуття i безперервний розвиток управлінської компетентності в умовах додаткової професійної освіти.

Для нового покоління керівників, схильних до здійснення інноваційного менеджменту, стає реальною необхідністю володіння інноваційним, системнокреативним мисленням, активізує креативність в процесі вирішення існуючих проблем і пошуку нових можливостей для розвитку освітнього закладу.

Оскільки інновація виступає як особливим чином організована діяльність, самовідновлювана, то вона вимагає певну сукупність характерологічних рис інноваційної особистості директора мистецької школи, серед яких:

- потреба в змінах, вміння піти від влади традицій, визначаючи точки розвитку і адекватні їм соціальні механізми;

- наявність креативності як особистісної якості і творчого, інноваційного мислення;

- готовність і здатність знаходити ідеї і використовувати можливості їх оптимальної реалізації;

- системний, прогностичний підхід до відбору і організації нововведень;

Професіоналізм педагога: теоретичні й методичні аспекти. - Вип. 7. - Слов'янськ, 2018. 
- здатність орієнтуватися в стані невизначеності і визначати допустимий ступінь ризику;

- готовність і здатність до подолання перешкод;

- розвинена здатність до рефлексії, самоаналізу.

Безумовно, це не вичерпний ряд рис інноваційного директора мистецької школи, але необхідний і достатній для позначення інноваційності як типового якості особистості керівника.

Висновки 3 дослідження та перспективи подальших наукових розвідок у цьому напрямі. Виходячи 3 вищезазначеного, можна зробити висновок, що управлінська компетентність директора мистецької школи $\epsilon$ складним інтегративним новоутворенням особистості і у своїй структурі має чотири основних функціональних компоненти: когнітивний, організаційний, комунікативний, рефлексивний. Запропонований критеріально-рівневий аналіз управлінської компетентності директора мистецької школи відкриває перспективи для подальших досліджень методів іiі формування та пошуку сучасних шляхів іiї розвитку в контексті реформування мистецької освіти.

\section{СПИСОК ВИКОРИСТАНИХ ДЖЕРЕЛ}

1. Закон України «Про освіту». № 2145-VIII (2017, 05 вересня). Взято 3: http://zakon3.rada.gov.ua/laws/show/2145-19

2. Концепція сучасної мистецької школи (Наказ Міністерства культури України від 20.12.2017 № 1433). Взято http://mincult.kmu.gov.ua/document/245318429/Концепція_текст.docx

3. Васильченко, Л. В. (2007). Управлінська культура і компетентність керівника. Харків : Основа.

4. Даниленко, Л. І. (2004). Підготовка керівника середнього закладу освіти. Київ : Міленіум.

5. Козир, А. В. (2017). Акмеологічні тенденції розвитку мистецької освіти в сучасному вимірі. Професіоналізм педагога: теоретичні й методичні аспекти, 6, 5-12. Взято 3: http://pptma.dn.ua/files/2017/6/1.\%20Kozyr\%205-12.pdf

6. Локшин, В. С. (2015). Професійна компетентність майбутніх менеджерів соціокультурної сфери в контексті модернізації вищої освіти. Автореф. дис. д-ра пед.наук. Київ.

7. Маслов, В. І. (2002). Наукові засади визначення змісту підвищення кваліфікації та підготовки керівників загальноосвітніх навчальних закладів. Післядипломна освіта в Україні, 2, $63-66$.

8. Поліщук, В. П. (2012). Психологічний аналіз управлінської діяльності директора навчально-виховного закладу. Шлях освіти, 7, 12

9. Сорочан, Т. М. (2005). Підготовка керівників шкіл до управлінської діяльності: теорія і практика. Луганськ : Знання.

\section{СТРУКТУРА УПРАВЛЕНЧЕСКОЙ КОМПЕТЕНТНОСТИ ДИРЕКТОРА ШКОЛЫ ИСКУССТВ В КОНТЕКСТЕ РЕФОРМЫ ХУДОЖЕСТВЕННОГО ОБРАЗОВАНИЯ}




\title{
Евгения Гринь
}

директор школы искусств г. Бахмут, учитель высшей категории, методист

г. Бахмут, Донецкая обл., Украина

https://orcid.org/0000-0001-6282-0387

genyakibkalo@gmail.com

Аннотация. В статье рассматривается вопрос глобальных изменений, которые происходят в системе художественного образования и выдвигают новые требования к управлению художественной школой, и в свою очередь вызывают потребность в формировании нового уровня управленческой компетентности ее директора. Представлен анализ научных подходов к определению сущности и структуры управленческой компетентности директора художественной школы, опираясь на который, автор предлагает собственное толкование этого понятия, раскрывает структуру и характеризует основные компоненты управленческой компетентности с учетом современных общественных и образовательных инновационных процессов. Охарактеризованы критерии и уровни сформированности управленческой компетентности директора художественной школы. Определены характерологические черты инновационной личности директора художественной школы в контексте реформирования образования.

Ключевые слова: художественное образование; управленческая компетентность; художественная школа; директор; компоненты; критерии.

\section{THE STRUCTURE OF THE ART SCHOOL DIRECTOR'S ADMINISTRATIVE COMPETENCE IN THE CONTEXT OF ART EDUCATION REFORMING}

\author{
Yevheniia Hryn \\ Director of the Arts School of Bakhmuth \\ a teacher of higher category, methodologist \\ Bakhmut, Donetsk region, Ukraine \\ https://orcid.org/0000-0001-6282-0387 \\ genyakibkalo@gmail.com
}

\begin{abstract}
The article deals with the issues of global changes taking place in the art education system and introducing new requirements for the management of art schools. This process also causes the need to form a new level of administrative competence of an art school director. The problems of forming and developing the administrative competence of the heads of educational institutions of different types are described in the studies of L. Vasylchenko, V. Lokshyn, V. Maslov, T. Sorochan and others. The aim of the article is giving the author's view of the essence and structure of the art school director's administrative competence.

The analysis of scientific approaches to the definition of the essence and structure of the administrative competence of the director of the arts school is given, based on which, the author suggests the proper interpretation of this concept and reveals the structure and characterizes the main components of the administrative competence, taking into account modern social and educational innovation processes. The author emphasized that the administrative competence of the director of the art school is a complex integrative feature of the personality and it has four main functional components in its structure: cognitive, organizational, communicative, and reflexive. The criteria and levels of formation of the administrative competence of the director of the art school are described.
\end{abstract}


The characterological features of the innovative personality of the arts school director in the context of educational reform are determined, among them are the need for change; creativity as a personal quality and innovative thinking; readiness and ability to find ideas and use the possibilities of their optimal implementation; the ability to determine the permissible level of risk; readiness and ability to overcome obstacles; developed ability to reflect, self-examination. criteria.

Key words: arts education; administrative competence; art school; director; components;

\section{REFERENCES}

1. The Law of Ukraine On Education. No. 2145-VIII (2017, September 5). Retrieved from: http://zakon3.rada.gov.ua/laws/show/2145-19

2. The Concept of Modern Art School (Order of the Ministry of Culture of Ukraine dated December 20, 2017 No. 1433). Retrieved from: http://mincult.kmu.gov.ua/document/245318429/Concept_text.docx

3. Vasylchenko, L. V. (2007). Management culture and competence of the head. Kharkiv: Osnova.

4. Danylenko, L. I. (2004). Training the head of the secondary educational institution. Kyiv: Millennium.

5. Kozyr, A. V (2017). Acmeological trends of art education development in the modern dimension. Professionalism of the teacher: theoretical and methodical aspects, 6, 5-12. Retrieved from: http://pptma.dn.ua/files/2017/6/1.\%20Kozyr\%205-12.pdf

6. Lokshyn, V.S (2015). Professional competence of future managers of socio-cultural sphere in the context of modernization of higher education. Extended abstract of Doctor's thesis. Kyiv.

7. Maslov, V. I. (2002). Scientific fundamentals of the definition of the content of advanced training and preparation of the heads of general educational institutions. Pisliadyplomna osvita $v$ Ukraini, 2, 63 - 66.

8. Polishchuk, V. P. (2012). Psychological analysis of the managerial activity of the director of the educational institution. Shliakh osvity, 7, 12

9. Sorochan, T. M. (2005). Training of school principals for management activities: theory and practice. Luhansk: Znannia.

Матеріали надійшли до редакції 12.05.2018 р. 